Counsellia: Jurnal Bimbingan dan Konseling, 9 (2), 2019| 154-164

Copyright (O2019 Universitas PGRI Madiun

ISSN: 2088-3072 (Print) / 2477-5886 (Online)

Available online at: http://e-journal.unipma.ac.id/index.php/JBK

DOI: $10.25273 /$ counsellia.v9i2.5202

\title{
Identifikasi teknik pengubahan tingkah laku perpektif Abah Anom untuk penyembuhan korban Napza
}

\author{
Moh. Ziyadul Haq Annajih', Ishlakhatus Sa'idah ${ }^{2}$. \\ ${ }^{1}$ Bimbingan Penyuluhan Islam, STAI Miftahul Ulum, Pamekasan \\ najihas@gmail.com \\ ${ }^{2}$ Bimbingan dan Konseling Pendidikan Islam, IAIN Madura, Pamekasan \\ ishlakhatus@iainmadura.ac.id
}

\begin{abstract}
Abstrak
Penyembuhan melalui rehabilitasi yang berdasarkan nilai-nilai keagamaan dapat dianggap sebagai salah satu mediator yang sangat efektif dalam memberikan pembinaan kesehatan fisik, psikologis, mental, sosial, dan spiritual bagi korban Napza, maka penelitian ini bertujuan untuk menggali bentuk pendekatan yang berbasis nilai keagamaan yang dapat dijadikan sebagai teknik pengubahan tingkah laku terhadap korban Napza. Penelitian ini menggunakan pendekatan kualitatif dengan analisis hermeneutika bersusun. Data yang digunakan berupa data teks pemikiran Abah Anom, observasi, dan wawancara lapangan. Hasil penelitian ini adalah (1) proses pengubahan tingkah laku berfokus pada pola pikir; (2) analisis dan diagnosis berfokus pada pola pikir, kondisi psikologis yang tidak sehat, keyakinan, dan kebiasaan; dan (3) terdapat lima bentuk intervensi pengubahan tingkah laku melalu metode penyadaran diri, yaitu mandi taubat, shalat, dzikir, qiyamu al-lyail, dan puasa.
\end{abstract}

Kata Kunci : Teknik Pengubahan Tingkah Laku, Abah Anom, Napza

\begin{abstract}
Healing in the form of rehabilitation based on religious values occupies a strategic and organized position in providing psychological, mental, social, and spiritual physical health assistance for drug victims, then this study aims to explore the form of approaches based on religious values, can be used as a technique to change behavior towards drug victims. This study employs hierarchical hermeneutic analysis within qualitative approach. The data used are the text of Abah Anom's thoughts, observation, and field interview. The result of the study shows (1) the process of behavioural change focusing on the mindset; (2) analysis and diagnose focusing on the mindset, psychologicallyilled condition, belief, and habit; and (3) the presence of five intervention form of behavioural change through self awareness method, i.e. taubat shower, shalat, dzikr, qiyamu al lail, and fasting.
\end{abstract}

Keywords : Behavioural Change Technique, Abah Anom; Drugs

\section{PENDAHULUAN}

Sejauh ini, dominasi teori-teori konseling yang berasal dari Barat berdampak pada kakunya penerapan

konseling di lapangan yang dikarenakan tidak sesuainya dengan 
kondisi riil di lapangan. Selain itu, teori-teori konseling merefleksikan nilai-nilai budaya Barat, dikonstruk dan diaplikasikan dalam konteks Barat (McLeod, 2003). Oleh karena itu, banyak dilakukan upaya kontekstualisasi teori konseling ke dalam nilai-nilai setempat, baik secara teoritik maupun praktiknya. Salah satu penelitian yang telah dilakukan upaya kontekstualisasi ke dalam nilai-nilai setempat sebagaimana yang dilakukan oleh Samsul Arifin (2012) yaitu konseling at-tawazun yang berdasar pada nilai-nilai pesantren.

Munandir (1989) menegaskan pentingnya mempertimbangkan muatan nilai-nilai setempat dalam melakukan intervensi konseling sebagai upaya pengubahan tingkah laku konseli. Intervensi pengubahan tingkah laku dengan muatan nilainilai tasawuf (keagamaan) sebagaiamana yang dilakukan oleh pengasuh dan para ustadz Pondok Pesantren Al-Kautsar, Pamekasan merehabilitasi para korban Napza (narkotika, psikotropika, dan zat aditif) di LAPAS Narkotika Kelas II/A, Pamekasan. Selain itu, intervensi pengubahan tingkah laku dengan nilai tasawuf juga diterapakan oleh pengajar (di sekolah) pada pendidikan formal di pondok pesantren tersebut sebagai upaya pencegahan terhadap kenakalan remaja.

Konsep dan praktik tasawuf dalam tradisi tarekat (thoriqoh) merupakan salah satu sumber kekayaan yang terkandung dalam nilai-nilai keagamaan. Konsep dan praktiknya kerap digunakan sebagai dasar dalam membina dan membentuk perilaku. Proses pembinaan dan pembentukan perilaku dikenal dalam tasawuf dengan adanya tiga tahapan, yaitu takhali (pengosongan yang diridhoi dari sifat buruk), tahalli (pengisian sifat-sifat baik), dan tajalli (terungkapnya rahasia ketuhanan) (Aqib, 2005). Sejuah ini, tahapan tersebut menjadi dasar teknik, metode, dan landasan teoritis dalam mengkonstruk konseling yang bermuatan nilai-nilai keagamaan.

Konseling dengan muatan nilainilai tasawuf sebagai upaya ekspansi tataran dan ruang lingkup ke arah yang lebih luas, tidak hanya menjangkau tataran psikologis semata, melainkan merambah pada tataran moral-spiritual. Oleh karena itu, konseling dengan muatan nilai tasawuf tidak hanya berfokus pada proses penyembuhan, tetapi juga menekankan pada usaha peningkatan diri.

Terdapat banyak praktik tasawuf yang dapat diterapkan sebagai bentuk intervensi pengubahan tingkah laku. Praktik tasawuf diyakini mampu membentuk kepribadian seseorang yang "sehat", baik secara fisik maupun psikis. Beberapa penelitian terkait praktik tasawuf dalam mengatasi korban Napza, diantaranya adalah penelitian yang dilakukan 
oleh Supriatna (2012). Penelitiannya berdasar pada asumsi bahwa patologi sosial penyalahgunaan Napza merupakan suatu yang merusak tatanan kehidupan masyarakat dan generasi penerus di masa yang akan datang, sehingga penting dilakukan upaya pencegahan dan penyembuhan.

Penyembuhan dalam bentuk rehabilitasi berbasis nilai keagamaan merupakan suatu hal yang memungkinkan dikakukan saat ini dalam membina kesehatan fisik psikologis, mental, sosial, dan spiritual bagi korban Napza. Hasil penelitiannya menunjukkan bahwa rehabilitasi dengan muatan nilai keagamaan di Pondok Remaja Inabah XX yang dilaksanakan dengan metode tasawuf melalui amaliyah praktik Thoriqoh Qodiriyah wa an-Naqsabandiyah (TQN) dinilai sangat efektif.

Pada tahun 2016, Badan Narkotika Nasional (BNN) dan Pusat Penelitian Kesehatan (Puslikes) Universitas Indonesia melansir data bahwa remaja menyumbang angka $27,23 \%$ dari total jumlah penduduk Indonesia sebagai terdampak penyalahgunaan narkotika (tribunnews.com, 2017). Bahkan, angka sebenarnya bisa jauh lebih besar. Angka tersebut terindikasi kuat bahwa saat ini Indonesia "darurat narkotika" di kalangan remaja, khususnya. Perilaku penyalahgunaan narkotika ini menurut Abah Anom (Syaikh
Ahmad Shohibul Wafa Tajul Arifin) dalam kitabnya Akhlak al-Karimah merupakan penyakit batin yang menimbulkan akhlak tercela (Arifin, n.d.).

Mencermati kembali intervensi pengubahan tingkah laku yang dilakukan oleh pengasuh dan ustadz, khususnya pengajar pada pendidikan formal di Pondok Pesantren AlKautsar dalam menanggulangi kenakalan remaja pada santri, hal pertama kali yang dilakukan adalah tahap penyadaran diri. Hal demikian juga berlaku di LAPAS Narkotika Kelas II/A dalam praktiknya. Penyadaran diri disini diartikan sebagai bentuk penanaman kesadaran akan hubungan seorang hamba dengan Tuhannya. Penyadaran diri dari kelalaian manusia akan hakikat diri dan Tuhannya, demikian juga akan hakikat dan tujuan hidupnya (Aqib, 2005). Karena kelalaian inilah yang menjadikan seseorang berperilaku menyimpang.

Berdasarkan wawancara yang dilakukan bersama MN (04/03/2019) selaku ustadz sekaligus pengajar pada salah satu pendidikan formal di Pondok Pesantren Al-Kautsar. Ia menyampaikan bahwa "dalam menanam kesadaran santri yang berperilaku menyimpang, terkadang kami munggunakan metode muhasabah (intropeksi). Kemudian, kami suruh santri tersebut memperbanyak berdzikir, sholat, $d s b$." Selaras dengan pernyataan di atas, Abah Anom dalam muqadimah 
kitab Miftahus Shudur-nya mengutip pepatah Arab, yaitu "dalam mengobati manusia, yang pokoknya ialah rohnya dan hatinya, serta cara berpikir manusia itu."

Pernyataan di atas menyiratkan bahwa cara berpikir dianggap sebagai sasaran intervensi dalam pengubahan tingkah laku. Pola pikir dianggap mampu mengontrol dan mengarahkan sikap, perasaan, dan perilaku yang kemudian diarahkan kepada Allah dan hakikat dirinya. Bila hal ini ditarik ke dalam konteks konseling, maka tampak relevansinya dengan teori konseling REBT. Relevansi tersebut berdasar pada pola pikir sebagai fakta pengantara (activating event) dari keyakinan (belief) sebagai pengendali perasaan dan tingkah laku seseorang. Hal tersebut selaras dengan konsep skema A-B-C dalam teori REBT-nya Ellis (G. Corey, 2008).

Berdasarkan dari paparan di atas, peneliti bermaksud mengkaji teks pemikiran Abah Anom sebagai objek kajian ilmiah. Rasionalitas yang mendasari kajian ini berdasar atas potensi dan kekhasan pemikiran Abah Anom yang dapat dilihat dan ditelaah melalui karya-karya kitabnya dalam membina dan menyembuhkan perilaku penyalahgunaan Napza.

Berdasarkan paparan latar belakang di atas, maka rumusan masalah pada penelitian ini adalah (1) bagaimanakah deskripsi bentuk pengubahan tingkah laku korban Napza berdasarkan teks pemikiran Abah Anom? (2) bagaimanakah analisis dan diagnosis penyembuhan korban Napza berdasarkan pemikiran teks pemikiran Abah Anom? dan (3) bagaimanakah deskripsi bentuk perlakuan yang bisa dijadikan teknik pengubahan tingkah laku korban Napza berdasarkan teks pemikiran Abah Anom?

\section{METODE PENELITIAN}

Penelitian ini menggunakan pendekatan kualitatif yang bersifat deskriptif-interpretif. Prosedur pengumpulan data, analisis, dan interpretasi pada penelitian ini menggunakan strategi analisis hermeneutika bersusun (AHB). Dengan strategi AHB, penelitian ini berupaya memusatkan perhatian kepada pemakaan dan interpretasi teks terhadap pemikiran Syaikh Ahmah Shohibul Wafa Tajul Arifin dalam mengidentifikasi bentuk perlakuan yang dapat diadaptasi sebagai teknik pengubahan tingkah laku ke dalam konseling.

AHB adalah metode penafsiran atas penafsir (refleksif) yang tidak hanya berupa hermeneutika ganda (double hermeneutics), namun metode ini menjangkau penafsiran tingkat tiga (triple hermeneutics) (Mappiare-AT, 2013). Oleh karena itu, penelitian ini dapat digambarkan sebagai berikut: (1) data utama studi ini adalah hasil interpretasi pemikiran Abah Anom (tataran pertama); (2) 
data lapangan ini adalah hasil penafsiran atas interpretasi terhadap subjek penelitian (tataran kedua); dan (3) peneliti melakukan penafsiran keilmuan pada dua hasil penafsiran sebelumnya, yaitu interpretasi pemikiran Abah Anom dan subjek penelitian di lapangan (tataran ketiga).

Penelitian ini menggunakan alat pegumpul data berupa (1) dokumen teks pemikiran Abah Anom dalam kitab karangannya, yaitu Miftahus Shudur yang telah diterjemahkan oleh Prof. Aboebakar Atjeh dan Akhlak al-Karimah (Atjeh, n.d.). (2) wawancara mendalam (in-depth) atau tidak terstruktur bersama dengan subjek penelitian di lapangan: (a) AS (usia 59 tahun); (b) MN (usia 28 tahun); dan (c) AR (usia 25 tahun). Dan (3) observasi lapangan dilakukan sebagaimana pada lokasi penelitian di atas.

Teknik analisis data pada penelitian ini menggunakan strategi AHB yang berdasar pada kaidahkaidah AHB yang perlu diperhatikan dalam sebagaimana yang dipaparkan oleh Mappiare. AT (2013) pada penjelasan berikut ini:

1. Pengumpulan teks dilakukan secara komprehensif, namun terfokus.

2. Interaksi dengan fokus material empirik dengan mengkaji interpretasi dan pemahaman subjek penelitian terhadap teknik pengubahan tingkah laku dari hasil-hasil penelurusan teks dan meterial empirik lainnya.

3. Interpretasi dengan fokus menggarisbawahi makna-makna.

4. Refleksi produksi teks dan bahasa yang digunakan dengan fokus susunan teks sendiri, klaim terhadap otoritas, dan selektivitas suara atau wacana yang direpresentasikan teks.

5. Membaca ekstensif dan perbincangan metateori.

\section{HASIL DAN PEMBAHASAN \\ Hasil Penelitian}

Hasil penelitian ini menunjukkan bahwa intervensi pengubahan tingkah laku terdapat pada tiga aspek. Pertama, sasaran intervensi pengubahan perilaku. Kedua, analisis dan diagnosis. Ketiga, teknik-teknik pengubahan tingkah laku. Pada bagian pertama, ditemukan beberapa proses dalam membentuk perilaku yang bermasalah. Bermula dari hati dan pola pikir yang semata-mata berpandangan materialistik dan hedonis, yang kemudian memunculkan nafsu-nafsu (jiwa) tercela, sehingga melahirkan tingkah laku/perbuatan syahwat yang membentuk ketergantungan terhadap Napza.

Temuan di atas diperoleh dari konsep Abah Anom dengan subjek penelitian di lapangan AS. AS menjelaskan bahwa proses terbentuknya tingkah laku seseorang bermula dari "rusaknya hati" dan "pola pikir", lalu memunculkan nafsu 
syahwat, sehingga membentuk ketergantungan terhadap Napza. Oleh karena itu, AS meyakini bahwa sasaran intervensi pengubahan tingkah laku memusatkan pada hati dan pola pikir melalui metode penyadaran diri.

AS kembali menegaskan bahwa proses penyadaran diri ini sebagai bentuk penanaman kesadaran beragama, yaitu sadar akan eksitensi Tuhan dan hakikat dirinya. Karena menurutnya, kesadaran agama (religious conciousness) merupakan bagian dari aspek mental yang hadir (terasa) dalam pikiran dan dapat diuji melalui muhasabah (intropeksi). Dengan kesadaran inilah seseorang akan merasakan pengalaman agama (religious experience) yang merupakan unsur perasaan yang akan membawa kepada keyakinan yang dihasilkan oleh tindakan dan tingkah laku.

Kedua, analisis dan diagnosis ditemukan bahwa (1) pola pikir yang cendrung materialistik dan hedonis (duniawiyah), (2) kondisi resah dan gelisah yang berdampak pada kekosongan jiwanya, sehingga lapisan keimanan-Nya bocor, (3) pandangan terhadap suatu masalah menjadi sesuatu diyakini, dan (4) terdapat beberapa faktor penyalahgunaan Napza diantaranya adalah faktor kondisi lingkungan, baik keluarga atau masyarakat, gaya hidup, traumatik, bahkan unsur mistis.
Temuan di atas diperoleh dari konsep Abah Anom dengan subjek penelitian di lapangan, yaitu AS, $\mathrm{MN}$, dan AR. AS meyakini bahwa kesalahan berpola pikir yang sematamata cendrung materialistik dan hedonis atau memprioritaskan urusan duniawiyah daripada segala hal, maka akan berdampak pada munculnya nafsu-nafsu (jiwa) tercela, yaitu egocentros, polemos, dan eros, atau ghadlab dan syahwat, sehingga menjadi penyakit-penyakit psikologis pada dirinya. Kemudian, AS melanjutkan bahwa penyakit psikologis tersebut misalnya, merasa resa, gelisah dan sebagainya. Untuk mengobati keresahan dan kegelisahannya, maka muncul nafsu/syahwat untuk mendapatkan kenikmatan/ketenangan meski hanya sementara.

Sementara itu, MN dalam analisis dan diagnosis meyakini bahwa pandangan untuk mendapatkan kenikmatan/ketenangan semata-mata hanya bisa didapatkan dari pengguanaan Napza. Pandangannya ini seolah menjadi suatu keyakinan tersendiri bagi dirinya. Kemudian, AR juga memaparkan bahwa terdapat beberapa faktor yang ditemuinya, diantaranya adalah faktor lingkungan keluarga maupun masyakarat, gaya hidup, traumatik atau bahkan tak jarang unsur-unsur mistis.

Ketiga, teknik pengubahan tingkah laku terdapat lima bentuk intervensi pengubahan tingkah laku 
melalui metode penyadaran diri, yaitu (1) mandi taubat, (2) shalat, (3) dzikir, (4) qiyamu al-lyail, dan (5) puasa. Temuan tersebut diperoleh dari konsep Syaikh Abah Anom dengan subjek penelitian di lapangan, yaitu AS. AS menuturkan bahwa penyadaran diri dilakukan sebagai bentuk intervensi pikiran yang dilakukan dengan cara mengajak korban untuk melakukan intropeksi terlebih dahulu. Setalah hal itu dilakukan, kemudian pembina melakukan pembinaan/penyadaran melalui kelima bentuk intervensi pengubahan tingkah laku di atas.

Lebih lanjut lagi, AS menegaskan bahwa proses intervensi pikiran dilakukan dengan proses penanaman nilai-nilai ketuhanan. Dalam istilah thariqoh, proses ini disebut dengan "talqin dzikir" yang diberikan oleh mursyid atau wakil talqin mursyid. Kemudian, korban yang bersangkutan diarahkan untuk melaksanakan sejumlah amaliyah dalam rangka proses penyadaran diri (Atjeh, n.d.).

Hasil penelitian menyatakan bahwa pola pikir adalah fakta pengantara (activating event) dari keyakinan (belief) sebagai pengendali perasaan dan tingkah laku seseorang. Hal tersebut selaras dengan konsep skema A-B-C dalam teori REBT (Ellis, 1997). Temuan penelitian tersebut menunjukkan bahwa activating event "A" berpedoman dari bagaimana belief sedangkan "B" memandang terhadap suatu hal yang berdasar pada rasionalitas, logis, dan empiris.

\section{Pembahasan}

Analisis dan diagnosis dalam penelitian ini menunjukkan bahwa pola pikir/keyakinan sebagai pusat pengendali atau peristiwa pengantara (activating event). Hal tersebut selaras dengan skema A-B-C dalam teori REBT-nya Ellis (1997) yang menyatakan bahwa "A" berdasar pada activating event, "B" represented a person's Belief about that event merepresentasikan kepercayaan tentang peristiwa tersebut, dan "C" menunjukkan tanggapan emosional dan perilaku klien, atau konsekuensi untuk memegang keyakinan tertentu pada "B". Kekhususan temuan tampak ketika pendekatan REBT activating event " $A$ " telah diketahui berdasar pada bagaimana keyakinan "B" memandang suatu hal tertentu yang masih tampak umum berdasar pikiran yang rasional, logis, dan empiris. Namun, dalam temuan penelitian tidak selalu demikian. Bahkan, kerap kali keyakinan yang sehat adalah sesuatu yang mutlak dan sulit untuk diterima secara rasional karena keyakaninan tersebut banyak dipengaruhi oleh doktrin agama.

Hasil penelitian ini juga menunjukkan bahwa pola pikir dan keyakinan, syahwat, dan tingkah laku sebagai fokus dari proses tersebut. Pertama, pola pikir dan keyakinan, dalam teori REBT, Ellis berupaya mencermati pikiran dan keyakinan 
yang irrasional. Pikiran irrasional inilah yang akan menjadi sasaran intervensi pada dispute (Corey, 2013). Berkaitan dengan hal tersebut, Sharf (2012) menegaskan bahwa inti dari pendekatan REBT adalah untuk membantah pemikiran irasional; namun, banyak pendekatan kognitif, emotif, dan perilaku lainnya digunakan untuk membawa perubahan dan memenuhi tujuan klien.

Dalam menyasar pola pikir dan keyakinan ini klien digiring untuk berpikir dan mengkomparasikan konsekuensi perilakunya. Sederhananya, klien diajak untuk berpikir terhadap konsekuensikonsekuensi perbuatannya. Metode tersebut selaras dengan salah satu teknik pada pendekatan REBT, yaitu teknik referenting adalah suatu teknik yang dalam penerapannya meminta klien berpikir dan mempertimbangkan positif dan negatif atas perbuatannya. Pada saat itulah klien memetakkan positif dan negatif perbuatannya secara rasional (Jones, 2006). Kemudian, melalui teknik rational emotive imagery; klien dituntut untuk berpikir salah satu kejadian pengaktif lalu merasakannya "C" (Corey, 2008).

Tidak hanya itu, sasaran terhadap pola pikir dan keyakinan selanjutkan dikuatkan dengan sugesti-sugesti kepada klien sebagai disputing irrational beliefs, yaitu metode kognitif paling umum dari REBT terdiri dari terapis yang secara aktif membantah kepercayaan irasional klien dan mengajari mereka cara melakukan hal ini dengan tantangan mereka sendiri. (Corey, 2008)

Kedua, syahwat atau ghadlab merupakan sesuatu yang sangat dibutuhkan untuk memuhi kebahagiaan. Dalam teori Maslow (Haryanto, 2015), kebutuhan syahwat atau ghadlab merupakan kebutuhan fisiologis seseorang untuk mendapatkan suatu kebahagiaan. Namun, apabila kebutuhan fisiologis tersebut melebih atau mendominasi akal budi atau hati nurani, maka akan menghancurkan kebahagiaan tersebut. Oleh karena itu, al-Ghazali menegaskan pentingnya mengendalikan syahwat dan ghadlab tersebut (Al-Ghazali, n.d.).

Ketiga, tingkah laku, dalam teori behavioristik, Bandura berupaya mencermati pola belajar dengan mengamati (observasional learning) dan belajar dengan melakukan (enactive learning), dan tingkah laku manusia dipelajari dengan model (Jones, 2006).

Adapun teknik pengubahan tingkah laku untuk penyembuhan korban Napza ditemukan lima bentuk intervensi malului metode penyadaran diri. Pertama, mandi taubat, merupakan tradisi yang dilakukan oleh para sufi dan ahli tarekat. Secara teoritis ritual mandi taubat dianggap sebagai hydrotherapy, yaitu pengobatan dengan memanfaatkan air sebagai 
medianya. Sebagai hydrotherapy, mandi taubat diyakini sangat efektif meningkatkan kesadaran diri (self consciousness) dan penyembuhan dari segala penyakit (Mintarsih, 2001).

Kedua, shalat, merupakan metode penyadaran diri yang sangat diutamakan. Amaliyah shalat diyakini memiliki daya penyadar yang kuat. Dalam praktiknya, penyalahguna Napza dituntut untuk menambah instensitas sholatnya, baik sholat wajib maupun sunnah. Purba (2019) memaparkan bahwa shalat yang dilakukan sesuai dengan ajaran akan berdampak terhadap terbentuknya sikap-sikap terpuji dan menghindarkan perbuatan yang tidak sesuai dengan ajaran agama, melanggar norma-norma sosial dan budaya, menghilangkan banyak macam penyakit, serta mengembangkan kepribadian dan kematangan emosional.

Ketiga, dzikir, yaitu merupakan amaliyah pokok dalam pemikiran Abah Anom. Di dalamnya terdapat proses katarsis, pembalikan peran, dan pengulangan pernyataan diri yang rasional. Dengan dzikir, seseorang akan mengalami proses penyadaran dan perubahan kondisi psikologi. Penyadaran diri tersebut dicirikan dengan tujuh tingkat kesadaran atau yang lebih dikenal dengan tujuh jenis nafsu, yaitu nafsu amarah, nafsu mulhimah, nafsu muthmainnah, nafsu radliyah, nafsu mardliyah, nafsu lawwamah, dan nafsu kamilah (Aqib, 2005). Kedua metode tersebut (shalat dan dzikir) telah banyak dilakukan penelitian, salah satunya yang dilakukan oleh Hakim (2015) terkait dengan pengaruh terapi shalat dan dzikir terhadap kesadaran diri dan kontrol diri pada korban penyalahgunaan Napza. Hasil penelitiannya menunjukkan bahwa amaliyah sholat dan dzikir memiliki pengaruh yang sangat besar terhadap kesadaran diri dan kontrol diri.

Keempat, qiyamul lail atau shalat tahajud merupakan salah satu metode pembersihan jiwa. Pada praktiknya difokuskan untuk lebih memberikan dampak tazkiyatun nafsi dan dampak psikologis terhadap korban penyalahgunaan Napza. Dampak terhadap psikologis seseorang sebagaimana penelitian yang dilakukan oleh Eliza Alfareza (2018) yang menunjukkan bahwa shalat tahajaud dapat bermanfaat untuk gangguan stres, gangguan smatoform, gangguan disosatif, gangguan identitas gender atau gangguan seksual, gangguan kecemasan, gangguan skizfrenia atau psikotik, dan sebagainya.

Kelima, puasa merupakan amaliyah yang tak penting dari amaliyah lainnya. Puasa adalah bagian dari kontrol diri untuk menahan dari lapar dan nafsu. Maka dari itu, puasa dapat disebut sebagai self-control exercise (latihan kontrol diri). Dalam penelitiannya, Sutoyo (2013) memaparkan bahwa puasa 
yang dilakukan sesuai dangan ajaran agama dapat menumbuhkan sikap yang sabar dan tabah, memiliki sikap sosial, jujur, berpikiran jernih, terhindar dari perbuatan serta dapat mengendalikan dorongan-dorongan dan hasrat biologisnya (syahwat).

\section{SIMPULAN}

Penelitian ini menunjukkan bahwa intervensi pengubahan tingkah laku terdapat pada tiga aspek. Pertama, sasaran intervensi pengubahan perilaku. Kedua, analisis dan diagnosis. Ketiga, teknik-teknik pengubahan tingkah laku.

Pertama, beberapa proses dalam membentuk perilaku yang bermasalah. Bermula dari hati dan pola pikir yang semata-mata berpandangan materialistik dan hedonis, yang kemudian memunculkan nafsu-nafsu (jiwa) tercela, sehingga melahirkan tingkah laku/perbuatan syahwat yang membentuk ketergantungan terhadap Napza.

Kedua, analisis dan diagnosis ditemukan bahwa (1) pola pikir yang cendrung materialistik dan hedonis (duniawiyah), (2) kondisi resah dan gelisah yang berdampak pada kekosongan jiwanya, sehingga lapisan keimanan-Nya bocor, (3) pandangan terhadap suatu masalah menjadi sesuatu diyakini, dan (4) terdapat beberapa faktor penyalahgunaan Napza diantaranya adalah faktor kondisi lingkungan, baik keluarga atau masyarakat, gaya hidup, traumatik, bahkan unsur mistis.

Ketiga, teknik pengubahan tingkah laku ditemukan bahwa terdapat lima bentuk intervensi pengubahan tingkah laku melalui metode penyadaran diri, yaitu (1) mandi taubat, (2) shalat, (3) dzikir, (4) qiyamu al-lyail, dan (5) puasa.

\section{DAFTAR PUSTAKA}

Al-Ghazali, A. H. M. (n.d.). Kimiya' al-Sa'adah. Beirut: Dar al-Fikr.

Aqib, K. (2005). INABAH: Jalan Kembali dari Narkoba, Stress, dan Kesunyian Hati. Surabaya: PT. Bina Ilmu Surabaya.

Arifin, S. W. T. (n.d.). Akhlaqul Karimah/Akhlaqul Mahmudah: Berdasarkan Mudawamatu Dzikrullah. Tasikmalaya: Yayasan Serba Bakti Suryalaya.

Atjeh, A. (n.d.). Kunci Pembuka Dada Juz 1 - 2 (Terjemahan Miftahus Shudur). Tasikmalaya: Yayasan Serba Bakti Suryalaya.

Corey, G. (2008). Theory and practice and psychotherapy of counseling. Animal Genetics.

Corey, Gerald. (2013). Teori dan Praktek Konseling dan Psikoterapi (Cet. Ke-7). Bandng: PT. Refika Aditama.

Eliza, A. (2018). Zikir Sebagai Metode Pengobatan Pecandu NarkobaDi Padepokan Raudhoh Palembang. Universitas Islam Negeri Raden Fatah Palembang.

Ellis. (1997). The Practice of Rational Emotive Behavior Therapy. : New York: Springer Publishing Company, Inc.

Hakim, L. (2015). Pengaruh terapi religi shalat dan dzikir terhadap 
kontrol diri klien penyalahgunaan narkotika. Universitas Islam Negeri Maulana Malik Ibrahim.

Haryanto, R. (2015). Dzikir: Psikoterapi Dalam Perspektif Islam. AL-IHKAM: Jurnal Hukum \& Pranata Sosial, 9(2), 338.

Jones, R. (2006). Teori dan Praktek Konseling dan Terapi. Yogyakarta: Pustaka Pelajar.

Mappiare-AT, A. (2013). Tipe Metode Riset Kualitatif untuk Eksplanasi Sosial Budaya dan Bimbingan Konseling (Edisi Revi). Malang: Elang Mas.

McLeod, J. (2003). An Inroduction to Counselling (Third Edit). New York: Open University Press.

Mintarsih, L. (2001). Proses Penyembuhan pada Pecandu. Makalah Pada Seminar Sehari Peranan Olahraga Dalam Mencegah Dan Menanggulangi Madar. Jakarta.

Munandir. (1989). Bimbingan Sekolah di Indonesia: Corak yang Bagaimana? Naskah Pidato Pengukuhan Guru Besar IKIP Malang.

Purba, N., Sulistyawaty, S., \& Darwis, A. (2019). Penerapan Penyembuhan Bagi Pecandu Narkoba Dengan Membangkitkan Kesadaran Agama Melalui Pembetulan Nilai Pendidikan Ibadah, Akidah , Dan Akhlak Di Yayasan Rehabilitasi Rumah Ummi Sunggal. Amaliah: Jurnal Pengabdian Kepada Masyarakat, 3(2), 384-389.

Samsul Arifin. (2012). Konseling At-Tawazun (Titik Temu
Tradisi Pesantren dan Konseling). Conference Proceedings: Annual International Conference on Islamic Studies (AICIS) XII, 2149-2167.

Sharf. R, S. (2012). Theories of Psychotherapy and Counseling: Concepts and Cases (5th Editio). USA: Brooks/Cole Publishing Company.

Supriatna, A. (2012). Upaya Pencegahan dan Penyembuhan Patalogi Sosial Penyalahgunaan Narkoba Bebasis Nilai Keagamaan: Studi Deskriptif di Pondok Remaja Inabah XX Pesantren Suryalaya - Tasikmalaya. Universitas Pendidikan Indonesia.

Sutoyo. (2013). Bimbingan \& Konseling Islami (Teori \& Praktik). Yogyakarta: Pustaka Pelajar.

tribunnews.com. (2017). 27,32 Persen Usia Remaja Indonesia Pengguna Narkoba. In tribunnews.com. https://surabaya.tribunnews.com /2017/08/15/2732-persen-usiaremaja-indonesia-penggunanarkoba 